\title{
EFFECT OF IAA PRODUCED BY Pseudomonas aeruginosa 6A (BC4) ON SEED GERMINATION AND PLANT GROWTH OF GLYCIN MAX
}

\author{
${ }^{1}$ Department of Microbiology, Shardabai Pawar Women's College, Shardanagar, Baramati, Maharashtra, 413115 \\ ${ }^{2}$ Department of Microbiology, Vidya Pratishthan School of Biotechnology, Baramati, Maharashtra, 413133 \\ ${ }^{3}$ Department of Synthetic Biology, Vidya Pratishthan School of Biotechnology, Baramati, Maharashtra, 413133 \\ ${ }^{4}$ Principal, Vidya Pratishthan, Arts, Science and Commerce College Baramati, Maharashtra, 413133 \\ ${ }^{5}$ Department of Microbiology, Tuljaram Chaturchand College, Baramati, Maharashtra, 413102
}

Marathe $\mathrm{RJ}^{1 *}$, Phatake $\mathrm{YB}^{2}$, Shaikh $\mathrm{AC}^{3}$, Shinde $\mathrm{BP}^{4}$, Gajbhiye $\mathrm{MH}^{5}$

Received - February 11, 2017; Revision - April 26, 2017; Accepted - June 01, 2017

Available Online - June 30, 2017

DOI: http://dx.doi.org/10.18006/2017.5(3).351.358

\section{KEYWORDS}

IAA production

Pot assay

Soil analysis

Chlorophyll estimation

\begin{abstract}
The expansion of organic agriculture has increased the demand for alternatives to chemical fertilizers and pesticides. Compared with non- rhizospheric, bacteria from rhizosphere are likely to synthesize and release auxins as secondary metabolites because of ambient supplies of substrate exuded from the roots. In the present study ability of Pseudomonas aeruginosa 6A (bc4) to produce IAA and stimulate the growth of Glycine max (JS-335) plant was determined by pot culture assay. Results showed early germination of seeds (2 days) as compared to uninoculated seeds (4 days). Further, increase in the germination percent, shoot and root length of treated soyabean plant as compared with control was also reported. Analysis of leaves and soil samples were carried for the presence of micro and macro nutrient in inoculated pot and revealed that pot containing plant inoculated with test organism (PO) and plant inoculated with test organism and tryptophan (POT) showed significant increase in carbon, nitrogen, phosphorus and potassium, whereas leaves samples showed increase in nitrogen, phosphorus, iron and copper, when compared with the control (P). The chlorophyll estimation was carried out by using Arnon's method. High chlorophyll content was recorded in POT which contains tryptophan as a precursor of IAA synthesis pathway as compared to PO and control.
\end{abstract}

* Corresponding author

E-mail: rjndrmarathe@gmail.com (Marathe RJ)

Peer review under responsibility of Journal of Experimental Biology and Agricultural Sciences.

Production and Hosting by Horizon Publisher India [HPI] (http://www.horizonpublisherindia.in/).

All rights reserved.
All the article published by Journal of Experimental Biology and Agricultural Sciences is licensed under a Creative Commons Attribution-NonCommercial 4.0 International License Based on a work at www.jebas.org.

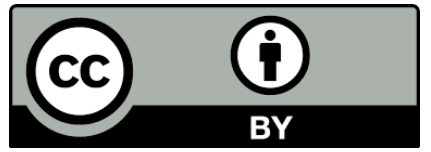




\section{Introduction}

With rapid discoveries of agriculturally important microbes and inoculum development strategies, nowadays biofertilizer shifted from conventional microbes to new range of bacteria and fungi. Directly or indirectly Plant growth promoting rhizobacteria (PGPR) induce plant growth. In direct mechanisms, these microorganisms produced some growth promoting substance such as indole-3-acetic acid (IAA) (Agrawal, 2014) which significantly contributes in, plant growth promotion (Miranda, 2012).

Free living microorganisms inhabiting in rhizosphere (Glick, 1995) of plants and some endophytes (Miliūtè \& Buzaitè,

2011) utilize various substrates, including acids, sugars, polysaccharides and ectoenzymes exuded from roots. This may account for $40 \%$ of root's carbon and are expected to synthesize and release auxins as secondary metabolites. IAA is the most common, naturally-occurring plant hormone of the auxin class. Auxin plays important role in accompanying various physiological functions like cell enlargement and division, tissue differentiation (Teale et al., 2006).

The IAA produced by the plants is proposed to act as a stimulator of cell proliferation, elongation and enhancement of host's uptake of minerals and nutrients from the soil (Suzuki et al., 2003). IAA also serves as a regulating agent for microbial cell differentiation (Matsukawa et al., 2007). Tryptophan is a primary precursor for the formation of IAA in plants and microorganisms. In bacteria, different biosynthetic pathways of IAA have been identified which have a high degree of similarity with those in plants (Miranda, 2012).

By producing plant growth regulators like IAA, gibberellic acid, cytokines and ethylene (Arshad \& Frankenberger, 1993), asymbiotic $\mathrm{N}_{2}$ fixation (Park et al., 2017), antagonism against phytopathogenic microorganisms by producing siderophores (Scher \& Baker, 1982; Marathe et al., 2015), antibiotics and cyanide (Flaishman et al., 1996), solubilization of mineral phosphates and other nutrients (De Freitas et al., 1997) PGPR promote plant growth. The Most popular bacteria studied and exploited as biocontrol agent and PGPR includes the species of Pseudomonas and Bacillus (Gajbhiye et al., 2013).

Many commercial applications of PGPR are being frequently tested; however, a better understanding of the microbial interaction will result in increase of success rate in field application (Gerhardson, 1990). Various species related to the genus Pseudomonas are widely distributed in nature and act as PGPR by nitrogen fixation, mineral solubilization, transformation of nutrients, production of phytohormones and siderophores and 1aminocyclopropane -1-caroboxylic acid (ACC) deaminase (Lugtenberg \& Kamilova, 2009).

Pseudomonas spp. has other traits in addition to IAA production hence these organisms have potential to develop as bioinoculants.
The effect of IAA on plant is being explored through ongoing plant inoculation studies. This strain as formulation of biofertilizer will help farmers to utilize the bacteria in fields which may reduces their dependences on chemical fertilizer. The results also suggested that IAA may act on common regulatory cascade leading to morphogenesis and secondary metabolism (Diemaite, 2004; Jeyanthi \& Ganesh, 2013). Present study deals with monitoring the ability of $P$. aeruginosa to produce plant growth promoters for stimulating plant growth along with effect of inoculants on soil profile as well as chlorophyll content of the leaves.

\section{Materials and Methods}

\subsection{Microorganism used during study}

In the present study, IAA producing strain of $P$. aeruginosa (NCBI accession number KX889395), previously isolated from rhizosphere soil (Egamberdiyeva, 2005) was used (Marathe et al., 2015). IAA producing ability of this isolate was already determined and production process was optimized by using Plackett-Burman design (Marathe et al., 2016).

\subsection{Effect of IAA producing isolates on plant growth}

\subsubsection{Pot Assay}

Pot assay was performed by using Glycine max (variety JS-335) in order to study the effect of IAA producing rhizospheric isolates on plant growth.

\subsubsection{Preparation of Soil for Pot Assay}

Different soil samples were collected from two localities namely Sangvi and Baramati of Pune district, Maharashtra. The samples were air dried under sunlight. Visible roots and debris were removed from the soil and discarded. The soil aggregations were broken down gently by crushing them using a wooden hammer. Grounded soil samples were then passed through $2 \mathrm{~mm}$ stainless steel sieve. The sieved samples were mixed thoroughly for making the composite sample and preserved in plastic bags.

\subsubsection{Inoculation of Seeds}

For inoculation, seeds of G. max were collected from the Baramati Agricultural Research Institute (BARI) and surface-sterilized with $0.5 \% \mathrm{NaCl}$ solution for 1-2 min, rinsed in sterilized distilled water (SDW) and dried under a sterile air stream. Cells of selected Pseudomonas strain was cultured under continuous shaking condition $(150 \mathrm{rpm})$ in King B broth at $28 \pm 1^{\circ} \mathrm{C}$ for $24 \mathrm{~h}$. Then culture was centrifuged at $7000 \mathrm{rpm}$ for $15 \mathrm{~min}$ at $4^{\circ} \mathrm{C}$. The supernatant was discarded and the pellets were washed with SDW and resuspended in same to obtain a population density of $10^{8} \mathrm{cfu}$ $\mathrm{ml}^{-1}$. The cell suspension was mixed with $1 \%$ carboxy methylcellulose (CMC) solution. The slurry was coated separately on the surface of G. max seeds and allowed to air-dry overnight in aseptic condition. The seeds coated with $1 \%$ CMC slurry without bacterial strain served as control (Deshwal \& Kumar, 2013). 


\subsubsection{Pot preparation}

Sterilized and air dried soil samples were added in to each pots amounting $1 \mathrm{~kg} /$ pot named as PO, POT, PIAA and P (Plant + Organism, Plant+ Organsim + Tryptophan, Plant+ Indol acetic acid and only Plant respectively ), four G. $\max$ seeds per pot were added in each pot. All the pots were arranged in completely randomized design in a net-house. The pots were watered twice daily. Positions of the pots were allowing equal exposure to sunlight. Thinning was done after 15 days, to raise healthy plants in each pot. Selected plants were grown in pots for three months under natural condition. All the experiments are carried out in triplicates. The plants were harvested manually by uprooting them carefully from the pots for analysis of root length, shoot length, leaves and soil analysis. The effect of Pseudomonas spp. on percent germination of seeds was also recorded.

\subsection{Analysis of Soil}

After completion of study, soil samples from all pots were separately mixed with water, allowed to equilibrate for at least an hour, and then the $\mathrm{pH}$ was measured. In present study standard procedure of salinity testing was used in which EC of a solution extracted from a soil was measured. The standard laboratory test for soil carbon is dry combustion using an elemental analyzer. These instruments heat a small sample (usually a fraction of a gram) of dry pulverized soil to around $900^{\circ} \mathrm{C}$ and measure the $\mathrm{CO}_{2}$ gas that is a combustion product.

For determination of available nitrogen from the soil, alkaline permanganate method was used. For preparation of sample, $20 \mathrm{gm}$ of soil was taken in $800 \mathrm{ml}$ dry Kjeldahl flask for this $20 \mathrm{ml}$ water was added and swirl. Then $1 \mathrm{ml}$ of liquid paraffin and few glass beads were added to prevent frothing and bumping respectively, during distillation. Then $100 \mathrm{ml}$ each of $0.32 \% \mathrm{KMnO}_{4}$ and $2.5 \%$ $\mathrm{NaOH}$ solution were added in to the flask and immediately connected to the ammonia distillation apparatus. The contents were distilled in Kjeldahl assembly at a steady rate and the liberated ammonia was collected in a flask $(250 \mathrm{ml})$ containing $20 \mathrm{ml}$ of boricacid solution (containing indicator). With the absorption of ammonia, the pink color of boric acid solution turns to green. Nearly $100 \mathrm{ml}$ of distillate was collected in about 30 minutes. The content was titrated with $0.02 \mathrm{~N} \mathrm{H}_{2} \mathrm{SO}_{4}$ to the original shade (pink). Blank correction was made for final calculations (George et al., 2013).

For determination of phosphorus, $2.5 \mathrm{gm}$ of soil sample was mixed with one tea spoon of activated carbon (Darco-G.60) in a $250 \mathrm{ml}$ conical flask. Then $50 \mathrm{ml}$ of $0.5 \mathrm{M} \mathrm{NaHCO}_{3}$ solution (extracting solution) was added in it. After addition, flask was shaken for half an hour on a suitable shaker and suspension was filtered immediately after shaking. From the filtrate $5.0 \mathrm{ml}$ were transfer into $25.0 \mathrm{ml}$ volumetric flask in which drop by drop $5.0 \mathrm{ml}$ ammonium molybdate were added with constant shaking till $\mathrm{CO}_{2}$ evolution ceases. It was followed by the addition of $1.0 \mathrm{ml}$ dilute solution (working solution) of $\mathrm{SnCl}_{2}$. Finally the color intensity was measured on a photoelectric colorimeter, ten minutes after the addition of stannous chloride solution. Available phosphorus in ppm was calculated by using standard curve. $\mathrm{P}$ in $\mathrm{Kg} / \mathrm{ha}$ was then calculated by using following formula.

Available Phosphorus $(\mathrm{P})$ of soil $(\mathrm{Kg} / \mathrm{ha})=$

$$
\text { A x volume of } \frac{\text { extractant }}{\text { volume of aliquot }} \times \frac{1}{\text { wt.of soil }} \times 2.24 \times \frac{10^{6}}{10^{6}}
$$

For determination of potassium, sodium, iron, zinc and copper $5 \mathrm{gms}$ of soil was taken in a $100 \mathrm{ml}$ conical flask and $25 \mathrm{ml}$ neutral normal ammonium acetate of $\mathrm{pH} 7$ were then added. Content of the flask were then shaken for $5 \mathrm{~min}$. and immediately filtered through Whatman no.1 filter paper. First few $\mathrm{ml}$ of the filtrate was rejected. Finally by using known standard solutions of potassium, sodium, iron, zinc and copper present in the extract was determined by flame photometer using $\mathrm{K}, \mathrm{Na}, \mathrm{Fe}, \mathrm{Zn}$ and $\mathrm{Cu}$ filter respectively (Chapman \& Pratt, 1978; George et al., 2013).

\subsection{Analysis of Leaves}

The leaf analysis (leaf analysis, tissue analysis or foliar analysis) is the most precise method of monitoring plant nutrient levels. For analysis, $500 \mathrm{mg}$ of green, healthy and fresh leaves were grind well with a pestle and mortar in $5-10 \mathrm{ml}$ of the phosphate buffer $(0.1$ $\mathrm{M}, \mathrm{pH}$ 7.0). The content was centrifuge at $5000 \mathrm{rpm}$ and supernatant was used for further study. Standard protocols were used to determined nitrogen, phosphorus, potassium, iron, manganese, zinc and copper.

\subsection{Estimation of Chlorophyll}

The leaves sample collected from different pots were analyzed for chlorophyll content by using Arnon method (1949). 0.1 gm of fresh plant material (leaf sample) was collected in a clean beaker. Then sample was ground to produce fine pulp with addition of 10 $\mathrm{ml}$ of $80 \%$ acetone. Centrifuge the extract at $5000 \mathrm{rpm}$ for $5 \mathrm{~min}$. and supernatant was transferd to a test tube which was covered in black marble paper to avoid photo oxidation of chlorophyll. Finally absorbance of the solution was recorded at $663 \mathrm{~nm}$ (chlorophyll a) and $645 \mathrm{~nm}$ (chlorophyll b) against the solvent (80\% acetone) blank (Arnon, 1949; Hiscox \& Israelsta, 1979; Rajalakshmi \& Banu, 2015). Chlorophyll in $\mathrm{mg}$ per gm of tissue was then calculated by using following formula (Ambawade \& Pathade, 2013; Kumar et al., 2014).
1. Chlorophyll a (mg/gmtissue) $=12.7(\mathrm{~A} 663)-2.69(\mathrm{~A} 645) \times(\mathrm{V} / 1000 \mathrm{xW})$
2. Chlorophyll b (mg /gm tissue) $=22.9(\mathrm{~A} 663)-4.68(\mathrm{~A} 645) \times(\mathrm{V} / 1000 \mathrm{x} \mathrm{W})$
3. Total chlorophyll $(\mathrm{mg} / \mathrm{gm}$ tissue $)=20.2(\mathrm{~A} 663)+8.02(\mathrm{~A} 645) \times(\mathrm{V} / 1000 \mathrm{x} \mathrm{W})$
Where,
$\mathrm{A}=$ absorbance at specific wave length.
$\mathrm{V}=$ final volume of chlorophyll extract in $80 \%$ acetone.
$\mathrm{W}=$ fresh weight of tissue extract. 


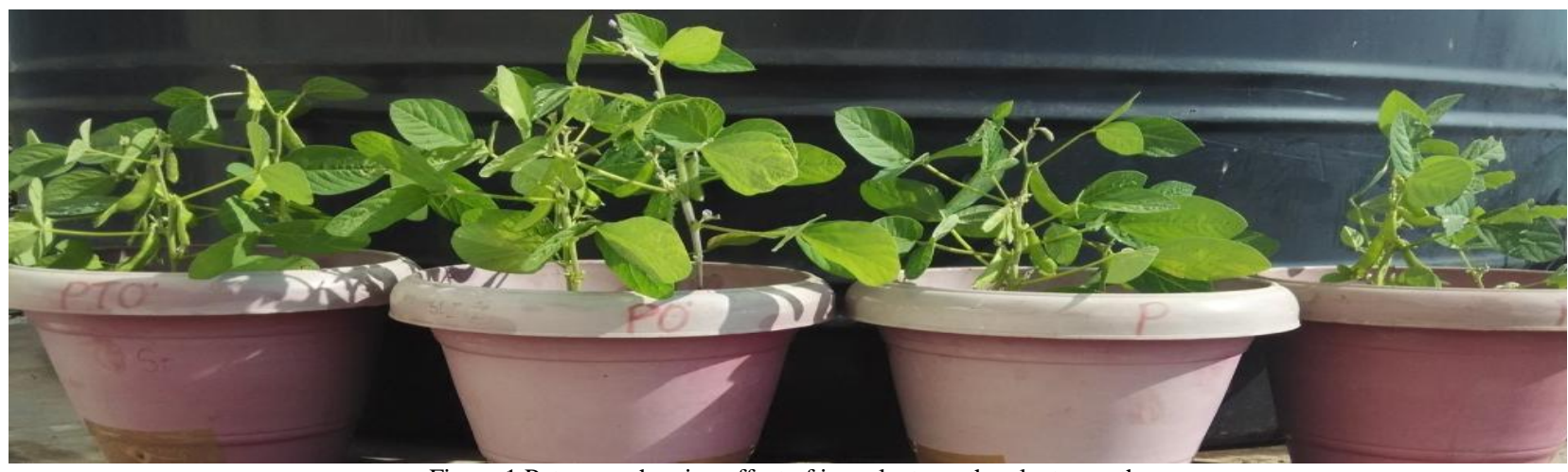

Figure 1 Pot assay showing effect of inoculants on the plant growth

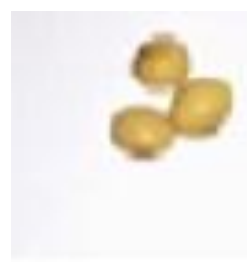

$\mathrm{PO}$

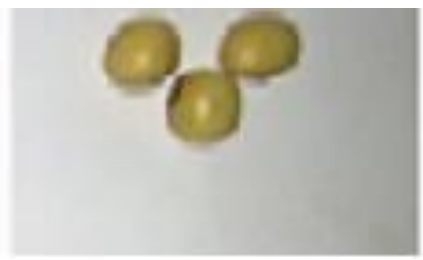

POT

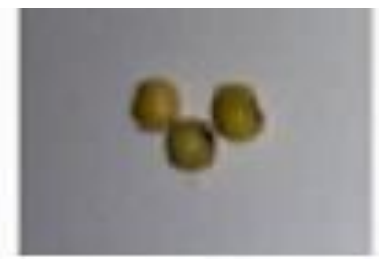

PIAA

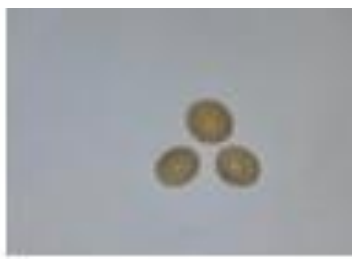

$\mathrm{P}$

Figure 2 Effect of $P$. aeruginosa on seed size and weight

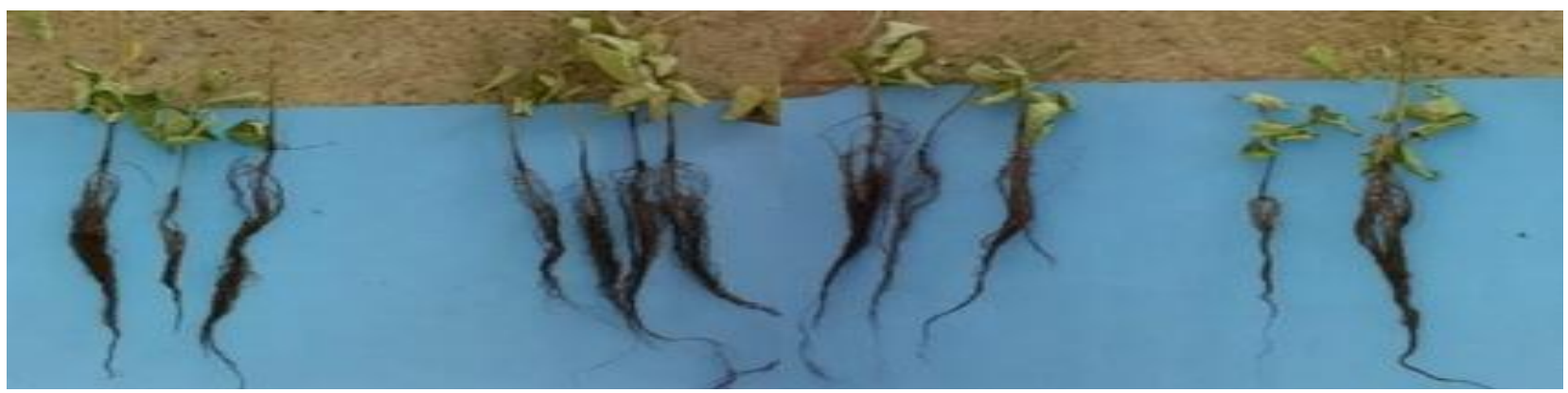

Figure 3 Effect of $P$. aeruginosa on the root and shoot length

Table 1 Effect of $P$. aeruginosa on seed germination, root length and shoot length of G. $\max$ (JS-335)

\begin{tabular}{|c|c|c|c|c|}
\hline Parameter & $\mathrm{PO}$ & POT & PIAA & $\mathrm{P}$ \\
\hline Seed Germination (\%) & 100 & 100 & 75 & 75 \\
\hline Germination Time (days) & 3 & 2 & 3 & 4 \\
\hline Root Length $(\mathrm{cm})$ (after 20 days) & $6.8 \pm 0.35$ & $7.5 \pm 0.20$ & $6.7 \pm 0.15$ & $5 \pm 0.34$ \\
\hline Shoot length $(\mathrm{cm})$ (after 20 days) & $11.3 \pm 0.10$ & $12.1 \pm 0.23$ & $9.8 \pm 0.30$ & $7.5 \pm 0.20$ \\
\hline
\end{tabular}

PO: Plant + P. aeruginosa, POT: Plant + P. aeruginosa + Tryptophan, PIAA: Plant + IAA, P: Plant

\section{Results and Discussion}

\subsection{Effect on Seed Germination, Root and Shoot Length}

The influence of $P$. aeruginosa $6 \mathrm{~A}$ (bc4) on seed germination and G. $\max$ (JS-335) plant growth was studied by pot culture technique. It was found that selected Pseudomonas strain have notable positive effect on seed germination, seed size and on the root and shoot length of the plant, as compared with the control $\mathrm{P}$ (uninoculated seeds) (Figure 1-3). Result of study showed 25\% increases in seed germination, in PO and POT pot, whereas no effect was observed in PIAA. Further, $36 \%, 50 \%$ and 33\% increases were reported in root length in pot containing PO, POT and PIAA respectively. After 20 days of inoculation, sudden improvement was reported in shoot length and this increase was $84 \%$ in PO while it was reported $90 \%$ and $73 \%$ in POT and PIAA respectively. The $50 \%$ reduction in time of germination was found in the POT while it was reported $25 \%$ reduction in both PO and PIAA as compared to control. Similar effect of different treatments was reported on seed size (Table 1). 


\begin{tabular}{|c|c|c|c|c|c|}
\hline 55 & & & & & Marathe et al \\
\hline S. No. & Parameter & $\mathrm{PO}$ & POT & PIAA & $\mathrm{P}$ \\
\hline 1 & $\mathrm{pH}$ & $8.14 \pm 0.10$ & $8.13 \pm 0.14$ & $7.70 \pm 0.11$ & $7.23 \pm 0.13$ \\
\hline 2 & Salinity $\left(\mathrm{d} / \mathrm{m}^{2}\right)$ & $0.19 \pm 0.08$ & $0.20 \pm 0.06$ & $0.34 \pm 0.06$ & $0.21 \pm 0.09$ \\
\hline 3 & Carbon (\%) & $0.75 \pm 0.08$ & $0.91 \pm 0.10$ & $0.71 \pm 0.01$ & $0.60 \pm 0.08$ \\
\hline 4 & Nitrogen $(\mathrm{kg} / \mathrm{Ha})$ & $180 \pm 9.00$ & $216 \pm 11.60$ & $161 \pm 10.00$ & $144 \pm 7.40$ \\
\hline 5 & Phosphorus (Kg/Ha) & $5.0 \pm 0.40$ & $5.0 \pm 0.43$ & $4.42 \pm 0.38$ & $3.76 \pm 0.29$ \\
\hline 6 & Potassium (kg/Ha) & $570 \pm 15.41$ & $604 \pm 14.12$ & $579 \pm 8.15$ & $562 \pm 18.71$ \\
\hline 7 & Sodium (ppm) & $2.18 \pm 0.14$ & $2.21 \pm 0.26$ & $2.11 \pm 0.12$ & $2.09 \pm 0.10$ \\
\hline 8 & Lime (\%) & $8.82 \pm 0.12$ & $9.80 \pm 0.19$ & $8.31 \pm 0.24$ & $8.35 \pm 0.17$ \\
\hline 9 & Iron(ppm) & $0.87 \pm 0.03$ & $0.87 \pm 0.09$ & $0.73 \pm 0.10$ & $0.75 \pm 0.07$ \\
\hline 10 & Zinc (ppm) & $0.01 \pm 0.00$ & $0.01 \pm 0.00$ & $0.01 \pm 0.00$ & $0.01 \pm 0.00$ \\
\hline 11 & Copper (ppm) & $0.47 \pm 0.02$ & $0.48 \pm 0.01$ & $0.45 \pm 0.01$ & $0.46 \pm 0.03$ \\
\hline
\end{tabular}

It has long been known that relative levels of plant hormones control seed dormancy and germination. The seed dormancy and ABA control of seed germination are also subject to strict modification by auxin (Liu et al., 2013). Mohite (2013), proposed that IAA produced by rhizosphere soil bacterial isolates were significantly augment the plant height and root length of crop plants along with increase in chlorophyll content when compared with control. IAA also induced proliferation of lateral roots and root hairs and thus increases nutrient absorbing surfaces; this may lead to greater rates of nutrient absorption. This in turn would significantly increase the shoot length of plant (Shahab et al., 2009).

\subsection{Analysis of Soil}

Based on soil analysis studies, pot inoculated with test organism and tryptophan exhibits slight alkaline $\mathrm{pH}$, when compared with un-inoculated and IAA containing pots. In the soil salinity testing the ability of the soil solution to conduct electricity was measured. The salinity of soil decreased in treatment containing PO and POT while it increased by $60 \%$ in soil inoculated with standard IAA. An elemental carbon exists in the soil in many forms, but for the purposes of this measurement and analysis was to estimate the availability of different carbon types in various plant tissues, results of study revealed the presence of three main forms of carbon viz. organic carbon, inorganic carbon and biochar. Among these three, organic soil carbon was derived from the living tissues such as plant leaves and roots, sap and exudates, microbes, fungi and animals. Further, charcoal also derives from living tissue, is often called biochar. It contains approximately 50 to 95 percent carbon by weight. Inorganic soil carbon is mineralized forms of carbon, such as calcium carbonate $\left(\mathrm{CaCO}_{3}\right)$ or caliche. It is more stable than most organic carbon as it is not food or fuel for microorganisms.

The soils from the pot containing PO and POT showed significant increase in level of soil carbon, nitrogen, phosphorus and potassium when they compared with the pot soil of P and PIAA. While all four pots do not show significant difference in sodium, zinc and copper contain. Lime percentage of the PO and POT pot increased by 0.47 and $0.45 \%$ respectively (Table 2). No significant change was reported in the lime percentage in the pot PIAA. Iron content of soil was also determined and it was found that isolated test organism have positive effect on iron when inoculated in soil singly or with tryptophan.

Addition of tryptophan stimulates the activities and efficiency of PGPR in the soil, by improving the ability of phytohormones production (Hassan \& Bano, 2015). The increase in yield of crop might be attributed to the greater microbial and enzymatic activities and rapid release of the nutrients in the soil (Gryndler et al., 2008). PGPR improve plant growth by enhancing the availability of nutrients (N, P and K) (Shaharoona et al., 2008). The increased phosphorus and nitrogen contents of treated soil, with tryptophan and PGPR might be attributed to phosphate solubilization and $\mathrm{N}$-fixing ability of Pseudomonas spp. (Schoebitz et al., 2013; Yadav et al., 2013). By the ability of nutrient balancing PGPR control trace element conc. of the soil and increase nutrients uptake (Saxena et al., 2013).

\subsection{Analysis of Leaves}

Dobereiner, 1995). Notable effect of inoculum on phosphorus, iron and copper content were also reported. Whereas no substantial effect is observed on the elements like potassium, manganese and zinc when compared with the control plant which is grown in absence of inoculums (Table 3). The leaves are the main photosynthetic organs of vascular plants and show considerable diversity in their geometries, ranging from simple to complex shapes. Recent work has suggested that the growth regulator auxin (IAA) has a prominent effect on initiation, elaboration and nutrient content of leaves (Scarpella et al., 2010). 
Table 3 Analysis of G.max leaves for availability of various nutrients

\begin{tabular}{|rccccc|}
\hline Sr. No. & Name of element & PO & POT & PIAA & P \\
\hline 1 & Nitrogen $\%$ & $0.89 \pm 0.05$ & $0.92 \pm 0.08$ & $0.81 \pm 0.10$ & $0.78 \pm 0.01$ \\
\hline 2 & Phosphorus \% & $0.042 \pm 0.001$ & $0.045 \pm 0.003$ & $0.036 \pm 0.008$ & $0.035 \pm 0.008$ \\
\hline 3 & Potassium \% & $0.77 \pm 0.08$ & $0.77 \pm 0.08$ & $0.75 \pm 0.06$ & $0.72 \pm 0.09$ \\
\hline 4 & Iron (ppm) & $125.00 \pm 2.0$ & $128.00 \pm 3.11$ & $121.00 \pm 4.05$ & $118.00 \pm 2.11$ \\
\hline 5 & Manganese (ppm) & $12.96 \pm 0.54$ & $13.20 \pm 0.29$ & $12.01 \pm 0.34$ & $12.58 \pm 0.46$ \\
\hline 6 & Zinc (ppm) & $8.38 \pm 0.08$ & $8.39 \pm 0.12$ & $8.00 \pm 0.15$ & $8.27 \pm 0.11$ \\
\hline 7 & Copper (ppm) & $22.24 \pm 0.64$ & $23.11 \pm 0.68$ & $19.14 \pm 0.49$ & $18.86 \pm 0.54$ \\
\hline
\end{tabular}

Table 4 Chlorophyll content in leaves of $G$. $\max$

\begin{tabular}{|cccccc|} 
Sr. No & Type of chlorophyll & $\begin{array}{c}\text { PO } \\
\text { (mg/gm tissue) }\end{array}$ & $\begin{array}{c}\text { POT } \\
(\mathrm{mg} / \mathrm{gm} \text { tissue })\end{array}$ & $\begin{array}{c}\text { PIAA } \\
\text { (mg/gm tissue) }\end{array}$ & $\begin{array}{c}\text { P } \\
\text { (mg/gm tissue) }\end{array}$ \\
\hline 1 & Chlorophyll a & $36.32 \pm 1.10$ & $36.98 \pm 0.90$ & $36.20 \pm 0.87$ & $35.55 \pm 0.12$ \\
\hline 2 & Chlorophyll b & $65.50 \pm 0.98$ & $66.69 \pm 1.06$ & $65.29 \pm 1.18$ & $65.20 \pm 0.87$ \\
\hline 3 & Total chlorophyll & $57.98 \pm 0.99$ & $59.04 \pm 0.78$ & $57.73 \pm 0.10$ & $56.62 \pm 0.57$ \\
\hline
\end{tabular}

\subsection{Estimation of Chlorophyll}

The main difference between two types of chlorophylls is a methyl moiety in chlorophyll a replaced by formyl group in chlorophyll b (Rajalakshmi \& Banu, 2015). All four pots showed highest content of chlorophyll $\mathrm{b}$ which was followed by total chlorophyll and chlorophyll a. The pot inoculated with Pseudomonas and tryptophan showed most prominent effect on all three type of pigments when compared with control, whereas pot containing only Pseudomonas and IAA shows negligible change in chlorophyll content. Plants inoculated with only test organism show moderate effect on chlorophyll (Table 4; Figure 4).

Larimi (2014) reported that, PGPR by symbiotic association and by producing growth promoter, significantly increased root development which leads to higher uptake of water and salts resulted in increased leaf area that ultimately affect chlorophyll content and rate of photosynthesis. The improved chlorophyll contents in leaves might be attributed to the ability of PGPR, residing there in to assist water and mineral absorption (Bashan et al., 2004). Our results are also in agreement with those obtained by Bekhit et al., (2005) and Kate et al., (2005) who studied effect of biological fertilizer on potato plants.

\section{Conclusion}

Results of study revealed that inoculated bacterial strain can produce more plant growth promoter in presence of tryptophan than the IAA. According to the results of soil and leaves analysis $\mathrm{N}, \mathrm{P}$ and $\mathrm{K}$ content of the pot containing tryptophan is much higher than the PO followed by PIAA and P, this may be because of the increasing production of IAA in presence of precursor. The results of chlorophyll analysis clearly indicate positive effect of inoculant on chlorophyll a, b and total chlorophyll content of the plant which ultimately affect the overall growth of plant. These findings

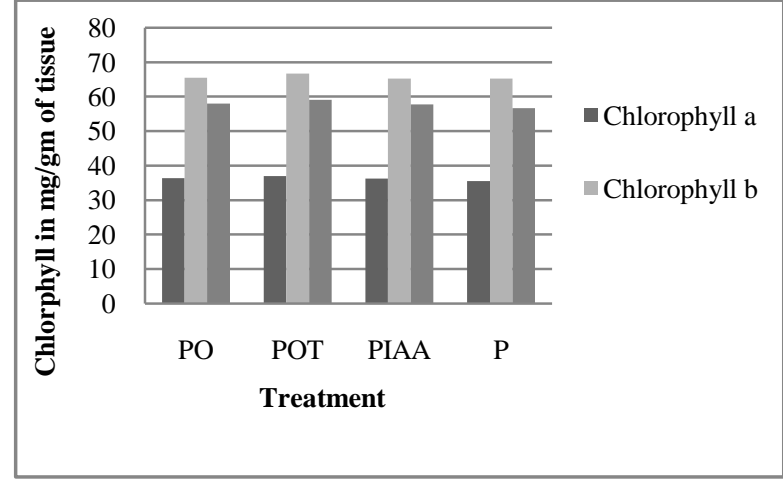

Figure 4 Comparative result of chlorophyll estimation

suggest that isolated strain of Pseudomonas may be used as a plant growth promoting bacteria and can be used to develop bioinoculants and biofertilizer for enhancing the growth of crop plant.

\section{References}

Agrawal PK (2014) Isolation and characterization of indole acetic acid producing plant growth promoting rhizobacteria from rhizospheric soil of Withania somnifera. Journal of Biological and Scientific Opinion 2: 2321-6328.

Ambawade MS, Pathade GR (2013) Production of indole acetic acid (IAA) by Stenotrophomonas maltophilia BE25 isolated from roots of Banana (musa spp.). International Journal of Science and Research 4: 2644-2650.

Arnon DI (1949) Copper enzymes in isolated chloroplasts. Polyphenoxidase in Beta vulgaris. Plant Physiology 24: 1-15. 
A rshad M, Frankenberger W (1993) Microbial production of plant growth regulators. In: Meeting FB (Ed.), Soil Microbial Ecology, Marcel Dekker lnc., New York.

Bashan Y, Holguin G, De-Bashan LE (2004) Azospirillum- plant relationships: physiological, molecular, agricultural and environmental advances. Canadian Journal of Microbiology 50: 521-577. DOI: 10.1139/w04-035.

Bekhit SR, Hassan AH, Ramadan MH, AlAnany AMA (2005) Effect of different levels and sources of nitrogen on growth, yield and quality of potatoes grown under sandy soil conditions. Annals of Agricultural Science, Moshtohor Journal 43: 381- 394.

Boddey RM, Dobereiner J (1995) Nitrogen fixation associated with grasses and cereals: Recent progress and perspectives for the future. Fertilizer Research 42: 241-250. DOI: 10.1007/BF00750518.

Chapman HD, Pratt PF (1978) Methods of Analysis for Soils, Plants and Waters. Available on http://trove.nla.gov.au/version/13891657 access on 25th April, 2017.

De Freitas JR, Banerjee MR, Germida JJ (1997) Phosphate solubilizing rhizobacteria enhance the growth and yield but not phosphorus uptake of canola (Brassica napus). Biology and Fertility of Soils 24: 358-364. DOI: 10.1007/s003740050258.

Deshwal V, Kumar P (2013) Production of plant growth promoting substances by Pseudomonads. Journal of Academia and Industrial Research 2: 2278-5213.

Diemaite J (2004) Peculiarities of the formation of indole-3- acetic acid- protein complexes in yeast Saccharomyces cerevisiae plasmalemma. Biologia 10: 36- 38.

Egamberdiyeva D (2005) Characterization of Pseudomonas species isolated from the rhizophere of plants grown in serozem soil, semiarid region of Uzbekistan. The Scientific World Journal 5: 501-509. DOI 10.1100/tsw.2005.64.

Flaishman MA, Eyal Z, Zilberstein A, Voisard C, Hass D (1996) Suppression of Septoria tritici blotch and leaf rust of wheat by recombinant cyanide producing strains of Pseudomonas putida. Molecular Plant- Microbe Interaction 9:642-645.

Gajbhiye MH, Sathe SJ, Marathe RJ, Deshmukh RB (2013) Antifungal Bacillus subtilis AFB22 from Pomegranate with Potential to control Fruit Rot. Research Journal of Biotechnology 8: 26-35.

Gaur AC (1990) Phosphate solubilizing microorganisms as biofertilizers. Omega Scientific Publishers, New Delhi.

George E, Rolf S, Ryan J (2013) Methods of soil, plants and water analysis. International center for agricultural research in dry areas. Third edition.2013.
Gerhardson B (1990) Biological substitutes for pesticides. Trends in Biotechnology 20:338-343. DOI: https://doi.org/10.1016/S01677799(02)02021-8.

Glick BR (1995) The enhancement of plant growth by free-living bacteria. Canadian Journal of Microbiology 41: 109-117. DOI: https://doi.org/10.1139/m95-015.

Gryndler M, Sudova R, Puschel D, Rydlova J, Janouskova M, Vosatka M (2008) Cultivation of high biomass crops on mine spoil banks: Can microbial inoculation compensate for high doses of organic matter. Bioresource Technology 99: 6391-6399. DOI: https://doi.org/10.1016/j.biortech.2007.11.059.

Hassan TU, Bano A (2015) The stimulatory effects of Ltryptophan and plant growth promoting rhizobacteria (PGPR) on soil health and physiology of wheat. Journal of Soil Science and Plant Nutrition 15: 190-201.

Hiscox JD, Israelsta GF (1979) A method for the extraction of chlorophyll from leaf tissue without maceration. Canadian Journal of Botany 57: 1332-1334. DOI: https://doi.org/10.1139/b79-163.

Jeyanthi V, Ganesh P (2013) Production, Optimization and Characterization of Phytohormone Indole Acetic Acid by Pseudomonas fluorescence. International Journal of Pharmaceutical and Biological Archives 4: 514-520.

Kate DM, Solanke AV, Tiwari TK, Nemade SM (2005) Growth and yield of potato cultivars as affected by integrated nutrient management system. Journal of Maharashtra Agricultural Universities 30: 236- 237.

Kumar A, Shukla UK, Singh A, Poonam AK, Prasad S, Singh SK, Kumar D (2014) Evolution of pseudomonas isolates from wheat for some important growth promoting traits. African Journal of Microbiology Research 8: 2604-2608.

Larimi SB, Shakiba M, Mohammadinasab AD, Vahed MM (2014) Changes in nitrogen and chlorophyll density and leaf area of sweet basil (Ocimum basilicum L.) affected by biofertilizer and nitrogen application. International Journal of Biosciences 5:256-265. DOI: http://dx.doi.org/10.12692/ijb/5.9.256-265.

Liu X, Zhang H, Zhao Y, Feng Z, Li Q, Yang HQ, Luan S, Li J, He ZH (2013) Auxin controls seed dormancy through stimulation of abscisic acid signaling by inducing ARFmediated $A B I 3$ activation in Arabidopsis. Proceeding of the National Academy of Science 110: 15485-15490. DOI: 10.1073/pnas.1304651110.

Lugtenberg B, Kamilova F (2009) Plant growth promoting rhizobacteria. Annual Reviews of Microbiology 63:541-56.

Marathe RJ, Phatake YB, Shinde NS, Mahamuni SV (2016) Application of statistical design for optimization of production process of IAA by using novel pseudomonas aeruginosa $6 \mathrm{~A}$ (bc4). 
Advance Journal of Pharmaceutical and Life Science Research 4 : 60-67.

Marathe RJ, Phatake YB, Sonawane AM (2015) Bioprospecting of pseudomonas aeruginosa for their potential to produce Siderophore process optimization and evaluation of its bioactivity. International Journal of Bioassays 4:3667-3675. DOI: https://doi.org/10.21746/ijbio.2015.02.009.

Matsukawa E, Nakagawa Y, Iimura Y, Hayakawa M (2007) Stimulatory effect of indole-3- acetic acid on aerial mycelium formation and antibiotic production in Streptomyces spp.

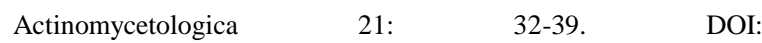
http://doi.org/10.3209/saj.SAJ210105.

Miliūtė I, Buzaitè O (2011) IAA production and other plant growth promoting traits of endophytic bacteria from apple tree. Biologija 57: 98-102. DOI: https://doi.org/10.6001/biologija.v57i2.1835.

Miranda MVC (2012) Effects of microbial inoculants on biocontrol and plant growth promotion. $\mathrm{Ph}$. $\mathrm{D}$ thesis submitted to Ohio State University.

Mohite B (2013) Isolation and characterization of indole acetic acid (IAA) producing bacteria from rhizospheric soil and its effect on plant growth. Journal of Soil Sciences and Plant Nutrition 13: 638-649. DOI: http://dx.doi.org/10.4067/S071895162013005000051 .

Park CH, Yeo HJ, Park YJ, Morgan AM, Valan Arasu M, AlDhabi NA, Park SU (2017) Influence of Indole-3-Acetic Acid and Gibberellic Acid on Phenylpropanoid Accumulation in Common Buckwheat (Fagopyrum esculentum Moench) Sprouts. Molecules 22: 1-10. doi: 10.3390/molecules22030374.

Rajalakshmi K, Banu N (2015) Extraction and Estimation of Chlorophyll from Medicinal Plants. International Journal of Science and Research 4: 209-2012.

Saxena MJ, Chandra S, Nain L (2013) Synergistic effect of phosphate solubilizing rhizobacteria and arbuscularmycorrhiza on growth and yield of wheat plants. Journal of Soil Science and Plant Nutrition 13: 511-525.

Scarpella E, Barkoulas M, Tsiantis M (2010) Control of Leaf and Vein Development by Auxin. Cold Spring Harbor Perspectives in Biology 2: a001511. doi: 10.1101/cshperspect.a001511.

Scher FM, Baker R (1982) Effect of Pseudomonas putida and a synthetic iron chelator on induction of soil suppressiveness to Fusarium wilt pathogens. Ecology and Epidemiology 72: 1567-1 573.

Schoebitz M, Ceballos C, Ciampi L (2013) Effect of immobilized phosphate solubilizing bacteria on wheat growth and phosphate uptake. Journal of Soil Science and Plant Nutrition 13: 1-10. DOI: http://dx.doi.org/10.4067/S0718-95162013005000001.

Shahab S, Ahmed N, Khan N (2009) Indole acetic acid production and enhanced plant growth promotion by indigenous PSB'S. African Journal of Agricultural Research 4: 1312-1316.

Shaharoona B, Naveed M, Arshad M, Zahir ZA (2008) Fertilizer dependent efficiency of Pseudomonas for improving growth, yield and nutrient use efficiency of wheat (Triticum aestivum L.). Applied Microbiology and Biotechnology 79: 147-155. DOI: doi: 10.1007/s00253-008-1419-0.

Suzuki S, He Y, Oyaizu H (2003) Indole-3-acetic acid production in Pseudomonas fluorescens $\mathrm{HP} 72$ and its association with suppression of creeping bentgrass brown patch. Current Microbiology 47:138-143. doi:10.1007/s00284-002-3968-2.

Teale WD, Paponov IA, Palme K (2006) Auxin in action: Signaling, transport and the control of plant growth and development. Nature Reviews Molecular Cell Biology 7: 847-859. doi:10.1038/nrm2020.

Yadav S, Yadav S, Kaushik R, Saxena AK, Arora DK (2013) Genetic and functional diversity of fluorescent Pseudomonas from rhizospheric soils of wheat crop. Journal of Basic Microbiology 54: 425-437. DOI: 10.1002/jobm.201200384. 